\title{
Role of Revenue Mobilisation in the Growth and Development of Economy: A Case Analysis of Greece
}

\author{
Stavros Kalogiannidis ${ }^{1}$ \\ ${ }^{1}$ University of Western Macedonia, Greece \\ Correspondence: Stavros Kalogiannidis, Research Fellow, University of Western Macedonia, Kozani, 49 Megalou \\ Alexandrou str, Greece. E-mail: stavroskalogiannidis@gmail.com \\ Received: September 21, 2020 \\ Accepted: December 2, $2020 \quad$ Online Published: January 11, 2021 \\ doi:10.5430/rwe.v12n2p63 \\ URL: https://doi.org/10.5430/rwe.v12n2p63
}

\begin{abstract}
The mobilizing processes in terms of long-term impact on the economy of Greece and the euro zone. Thereafter, Troika was invented in order to facilitate Greece to overcome the historical crisis.

Research aim: The research has its focus on bureaucratic obstacles as well as complicated policies of fiscal laws under European Governance and regulations. Revenue mobilization might have influenced the country from a huge amount of debts. Since, it has been proved to be productive and effective, as per policies formed from the transferable Troika's policies. The contemporary crisis was handled with the resiliency of revenue mobilization along with digitization and innovations. The primary objective of the tax system is to raise the revenue that will aid in offering the nation with valuable services to the citizens, developing the nation, encouraging innovations and trade.
\end{abstract}

Period: the period of imposing revenue mobilization in the growth and the development of the economy of Greece.

Research method: After the whole research study the methodologies used is the secondary methods where no analysis or physical surveys are done. The primary methods are not used all the methods are based on the researches and the studies available. The effects that have been observed by the development functions and the statistics that is available after the influence of the growth after the revenue mobilization.

Country: The country taken here is GREECE

Research result: Revenue mobilization has been considered as an excellent choice for the development of the economy of a country. Taking help from the International Monetary Fund or the World Bank is considered as debt which has to be repaid, whereas revenue is collected from the country itself as taxation and tariffs. The revenue has helped the government to accumulate capital for various expenditures in the development of the nation such as building infrastructure and improving health facilities.

Keywords: Troika intervention, economic growth, revenue mobilisation, fiscal policies, governance, law, tax, resources, digitalisation

JEL codes: H2, H6, O47, F 63

\section{Introduction}

Revenue mobilization has been considered, as the first element of success in the 21 st-century economy. The higher is the revenue of the government; then it will be convenient to create capital for the activities and additional expenditures against such a development process, which includes its infrastructure, health, and education. The primary objective of the tax system is to raise the revenue that will aid in offering the nation with valuable services to the citizens, developing the nation, encouraging innovations and trade. The strengthening of the revenue mobilization in the developing countries is advisable, as it helps to build better taxation. As most of the countries are arising from the economic crisis they require extra revenue from their taxation policies as well. According to Popoola et al. (2018), to accomplish developing goals, domestic revenues are substantial, especially in low-income nations. There is a need for infrastructure in such countries and environmental challenges Most of the countries have enhanced their domestic revenue mobilization in order to strengthen their efforts and situations. The objective of the imposition was to compel the countries towards economic growth. 


\section{Taxation Problem Faced by Developing Nations}

Den Bogart et al (2018), opined that developing nations have to face taxation problems and need to overcome them so that they can increase the revenue collection and revenue mobilization. In the past decades, many countries have increased their taxation dramatically while in some it has remained the same. After the Great Recession of 2008, the effects on humankind have prevailed in most of the countries around the globe. In the western country, the USA, the effect was focused on a few States, but in Europe, nearly all the countries were affected. Although the North of Europe passed the crisis lightly, the rest of the countries had to endeavour the problem for the long term.

According to KAMARAS (2020), the crisis has been observed as an opportunity by most if the countries under the long-term effects in Europe. The core members of the euro zone along with its leader Germany grasped the opportunity and imposed neoliberals in order to aid the member countries especially in South Europe. In order to examine the effects of the neoliberal in the countries a non-democratic, technical system is formed and named as Troika. The Troika was established with the combined action of the European Commission, Central Bank of Europe, and the International money Fund and was one of the uncertain events in relation to the Great Recession. Although such programs have been adopted by the government of the USA and Western Europe it was a new program for the Southern European countries.

According to Hardiman et al (2019), the Troika intervened six times during the period from 2010 to 2018 which included three interventions in Greece. Greece was in debt and the interventions helped in comparison of the situation and helped the country to manage the economy and the revenue collection and mobilization

\section{Hypothesis of the Study}

The statistics that can be used to test the relationship between two or more things is called the hypothesis of the study. Here the study is about the revenue mobilisation in the growth and development of the economy of Greece. The study would focus if there is any relation between revenue mobilisation and taxation or not. The statistical hypothesis is done using two or more variables.

- Variables in the hypothesis- The independent where the researchers can control any change whereas the dependent variables which can only be observed or studied. Here in the study the revenue mobilization in the growth is the independent variable and the growth of the economy of Greece is the dependent variable that can only be observed

- The null hypothesis: the non remittance position that there is no relation between the variables is called a null hypothesis. The null hypothesis is recommended as $\mathrm{H} 0$ and the alternate hypothesis as $\mathrm{H} 1$.

H0- the research which determines that the revenue mobilization do not put any impact on the growth of the economy of Greece is the null hypothesis

H1- the research which determines that the revenue mobilization puts a positive impact on the growth of the economy of Greece

\section{Post Estimation on Digital Influences on Economic Manipulation}

Technology around the world was advancing rapidly and changes in the world economy accelerated. Previously, digitization and technological transformations were topics of interest only in the USA and Japan whereas other countries were unfamiliar with the process. Europe especially the euro zone was facing a crisis and the unemployment rate had increased and the jobs in the market were being taken by the low wage immigrants. On the other hand, countries like the USA, China, and Japan were improving their economic growth with the help of technological advances and innovations. Considering the growth and development of such countries, according to Jokanović et al. (2017), Greece would have taken up digitization, and ways of innovations for the improvement of its economic conditions. The digital platforms are evolving and the organizations in the market are also advancing in order to cope with the digital market and it helps in creating revenues and maintaining the economy along with the supply chain demands. As stated by, Kontolaimou and Skintzi (2018), with respect to digitization, Greece could have asked its policymakers to do the needful for grasping the opportunity of digital platforms as the organizations in the USA advanced with technology. As the education factors are strong for Greece, acquiring the changes for digitization would have been easier.

According to Khodaiji and Christopoulou, (2020), the financial crisis of 2007, the European countries were in the debt crisis and Greece was one of the countries to face the long term effects, such as high unemployment, taxation, corruption in politics, and so on. In order to handle the situation 'troika' was proposed by the European Commission, European Central Bank, and the International Monetary Fund in the year 2010, but the Greek government accepted the 
harsh terms and conditions from the creditors than it was proposed in the referendum.

Since, the crisis and the referendum, the economy of Greece has been extraordinarily owing to its orthodoxy. The initial fiscal was around 3.8 percent of the country's GDP in 2016, which rose to 4.1per cent in 2017 and again reduced to 3.8 percent in 2018. The main revenues have improved for the country by 14 percent of the GDP from 2007 to 2017 despite the great depression.

The Greek economy regained its growth, starting with 1.5percent in 2017 and the estimation for 2018 was 2.1 percentt and the prediction for 2019 is 2.4 percentt. The Gross Domestic Product decreased by 26 percent from 2007 to 2014 , and it was expected to be more than twenty percent in 2019. According to Meghiret al (2017), the economic growth is 2 percent annually; the country will not have to face the situations before the crisis till 2030 as predicted.

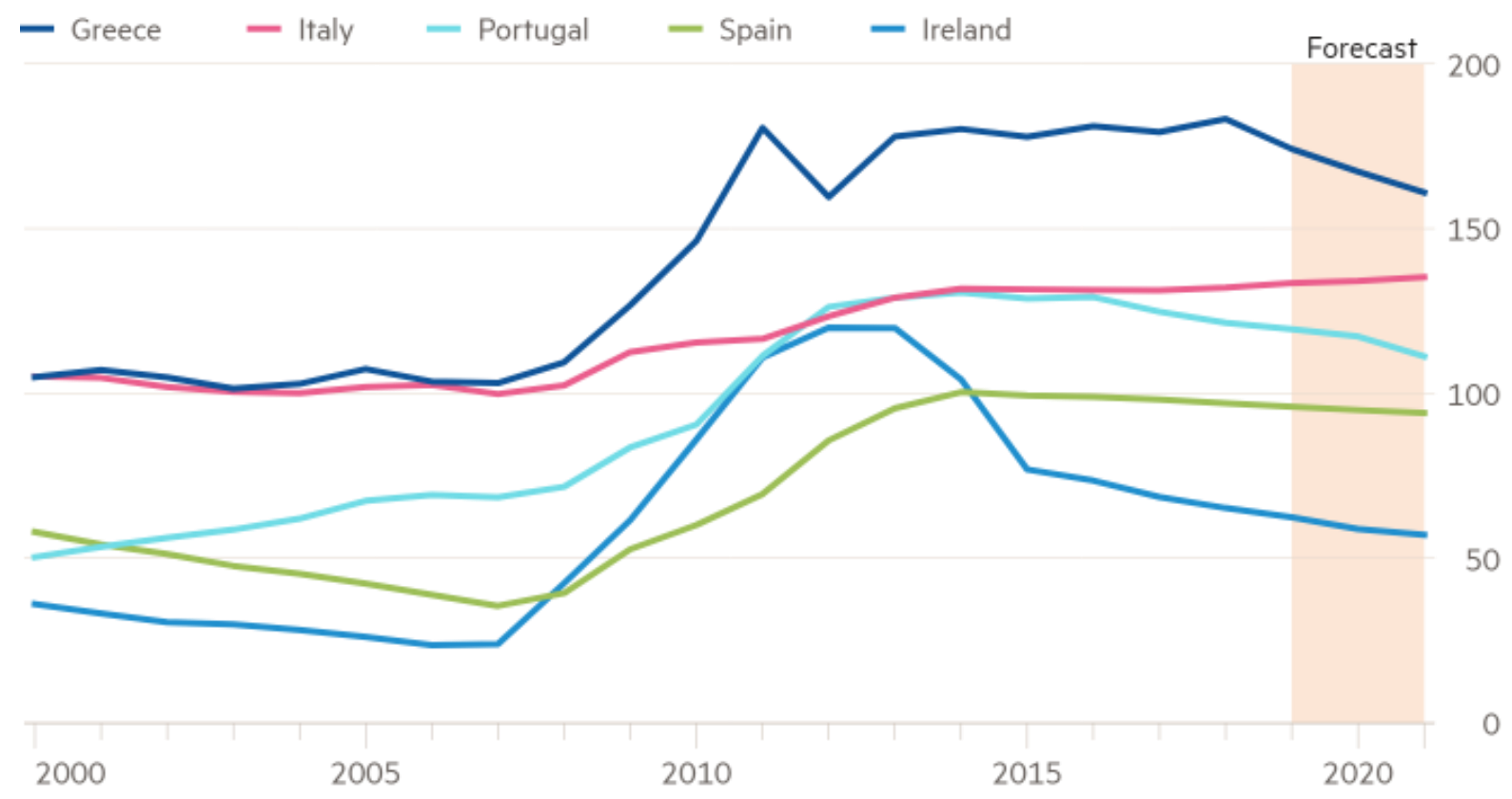

Source: IMF

(c) FT

Graph 1. The condition of Greece of all other nations in terms of debts is concerned

Source: Sotiropoulou, 2020

As stated by Karagiannaki et al. (2017), the education rate in Greece is higher in comparison to the rest of the European Union and has a tradition of involvement in science, the technological advances and innovations would have been well adopted by the citizens. The government could have asked its organizations to make use of technology, creating innovations for the upliftment of the economic conditions, especially in the production processes and it would also help the country in accumulating capital for building up the infrastructure.

Whereas, as stated by Sukhanov (2016), digital platforms are a source of enormous power, as it performs the role of the connecting agency. The role would have helped the country to understand the factors that would help to grow the economy. Although Greece has been a leading marine trader, with the help of technologies it would have been able to reach out to individuals, across the globe, which would help to bring in more revenue in the country as in form of tariffs.

Taking the example of Amazon in the USA Taplin (2017), Amazon has helped to grow the economy of the country in various aspects not only the retail business. With doorstep delivery, inviting interface, and its seamless processes have helped the firm to maintain it's top position in the market. The whole process has led to the raising if share values for the company along with improving the economy of the county. The technology advances used by Amazon lead the online searches directly to their page and with vast varieties of products, Amazon captured one out of every two dollars 
spent online in the USA. Considering the working of Amazon, Greece could have come up with advances that would help in increasing the trades in the global market, thus improving the economy and development along with revenues and its mobilization.

As influenced by Theodoropoulou (2016), it has been acknowledged that the unemployment rate is high in the country, as compared to the core depression scenario, as the crisis had damaged the economy, and its long-term effect still affects the growth rate. As per the International Monetary Fund, the country will have an expected growth of 2.2 percent in 2020 and 1.6 percent by 2021 after which the prediction is the slow growth of 1.2 percent annually. This shows that the country will have a show but a steady growth of the economy and recovery.

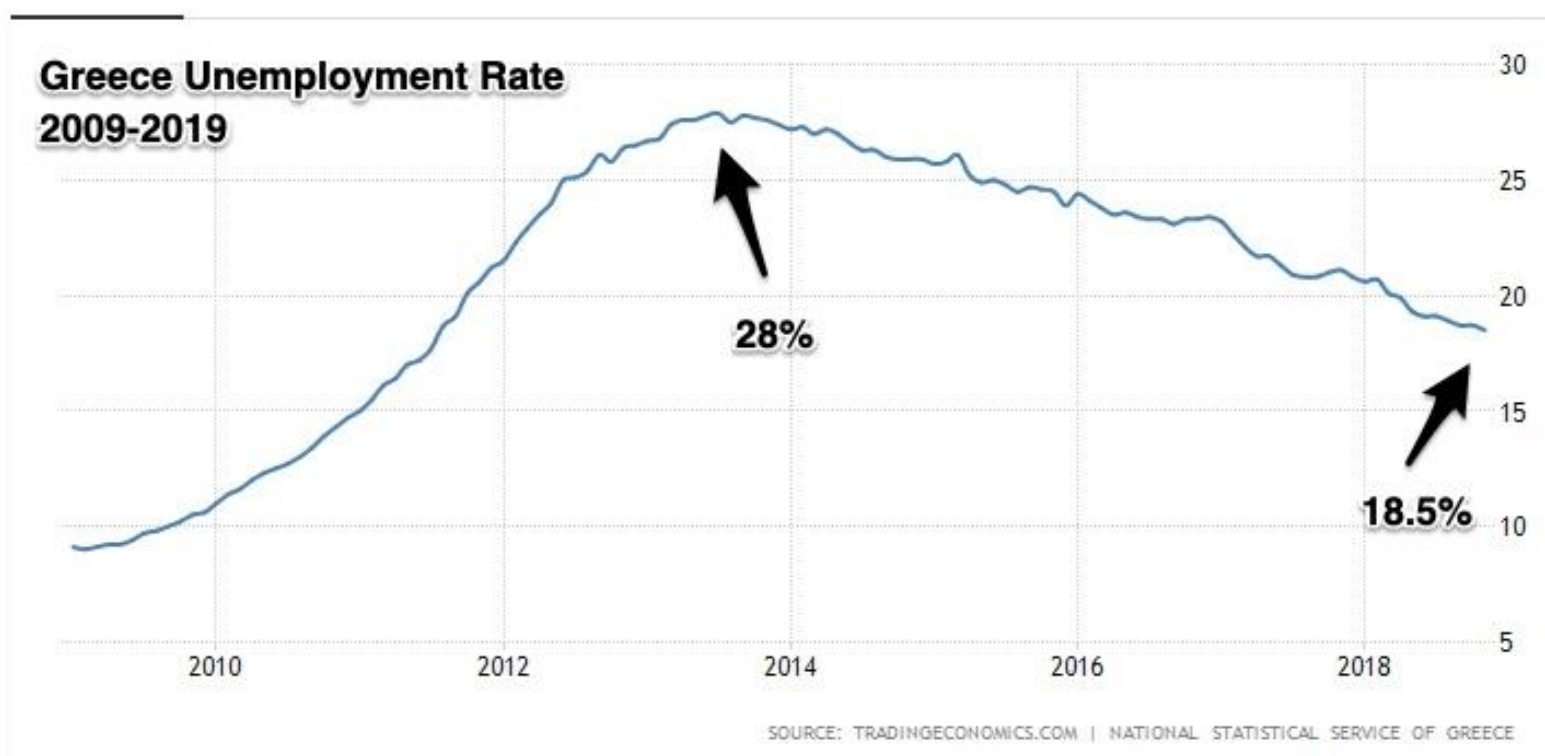

Graph 2. Unemployment rate in Greece

Source: Alexopouloset al.2018

According to Karavitis (2018), Greece is considered to be the most indebted country in the European Union, as the country has a current shortage of 3.4 percent of the GDP. To avoid the re-emergence of the debt issue, the county should recover the demands and maintain the equity flow. On the other hand, to maintain the agreed revenue constituting of 3.5 percent of the country's GDP will be a challenge.

According to Alexopouloset al (2018), the external environment will affect the country and this might lead to a reduction of tourists in Greece and that would be quite a blow to the country's economy. However, in order to continue the growth of the economy the country needs to work in improving the expenditure pattern of the citizens, modernize the administration, find ways to increase public investments encourage investments in the private sector and lift up the citizens' confidence in the politicians. All of this will help Greece to accelerate growth, reduce its debts, and move towards development.

\section{Possibility of Economic Aspects}

In order to overcome the crisis, the alternatives Greece could have accepted instead of the troika as suggested and created by the European Commission, European Central Bank, and the International Monetary Fund was the suspension of the illegal payments and unsustainable debts. As stated by Artavanis et al (2016), the country has a majority of shares in the Greek banks, around 80 percent, so it should have taken full supervision of the banks. This would have helped the country to protect the citizens' savings and improve the aspects of domestic loans. The country could have used its stake from the banks and used them in public sectors in order to protect the shareholders and small businesses in the county. Greece could have regained its control over the central bank and served the interest of its population. The most important part would have been the creation of electronic currency, for domestic use, and that would be a step in the digital economy. As stated by Lois et al (2019), the public sectors, on the other hand, could have 
raised pensions in order to help the public of the humanitarian needs by creating credit accounts for electronic currency. Various methods of payment could be used for the payment starting from taxes to transport, purchasing food, and so on. The electronic currency would have helped the Greek government to collect taxes from all the public services through the electronic payment method will be national management, additionally; the method would decrease the need for Euros in Greece that will save a lot of funds.

\subsection{Role of Social Involvement or Consumers on Enhancing Economy}

The essential goods and services tax should have reduced in order to provide everyone with basic necessities and even basic services can be made free of cost. As stated by Bitzenis and Vlachos (2018), the tax collected from citizens would provide revenue to the country, which on proper mobilization would help in growing the economy of the county and will be beneficial to overcome the crisis. The government could have created and implemented plans for creating jobs. For technological advances would also have helped the country to employ more population, as to run the system properly, labor will be required.

Moreover, according to Danchev et al. (2020), the country should show support to the public sector and small ventures as they firm the key components of the economy. For the citizens, loans should be provided with securities within the nation, this would also help in the redistribution of wealth and the inequalities would also decrease.

Though these are the alternatives that the Greek government could have adopted in order to improve its economic conditions, it is bound to the European Union and the Eurozone conditions, Greece adopted the Troika in order to enhance its economy and development. The troika applied methods to deal with the debts Greeks had borrowed, helping to clear the corruption among politicians. The process took ample time and strict rules which even led to protests across the country, though the situation did improve and still needs little more time to be on the peak.

\subsection{The Troika Interventions in Greece}

The troika has intervened in Greece three times in the period and the economic crisis has had various impacts in the country, from development to environmental and the drop in growth.

There is a linear relationship between the economic activities and the environment of any nation, the economic crisis in Greece showed some environmental benefits as the damage was reduced due to lesser discharge of pollutants from production and commercial activities. The major elements of pollution, like sulfur, carbon dioxide in the air drastically reduced especially from 2009 to 2012. Though the GDP could not be predicted, the troika observed the impact on the environment due to the crisis. According to Lois et al(2019), there will be an increase in the emissions with the growth in the economy and GDP of the country, and it is predicted that real growth would spread out till 2015.

\subsection{The Troika}

The troika, as created by the three, International Monetary Fund, the European Commission, and the European Central Bank was a mechanism to help the evaluation and negotiation of the economy and finances in the Eurozone. The troika relief in the reimbursement of the loans by the European countries and also had aid from the IMF. The methods used for the purpose were to be considered ultimate as the market was lacking finances. Though there were no further derailments in the process implementation, the primary and main elements of the program were to be evaluated.

The troika was not a formal player according to the public policies; it was concentrated in generating revenue for the country from especially loans for economic growth. According toMoschella (2016), the policy should be capable of pushing the obstacles and work through as per the preference. The creation of the Troika was more than just a policy, as it was involved in creating new unions, gaining help from the IMF, and helping the countries in the crises. 


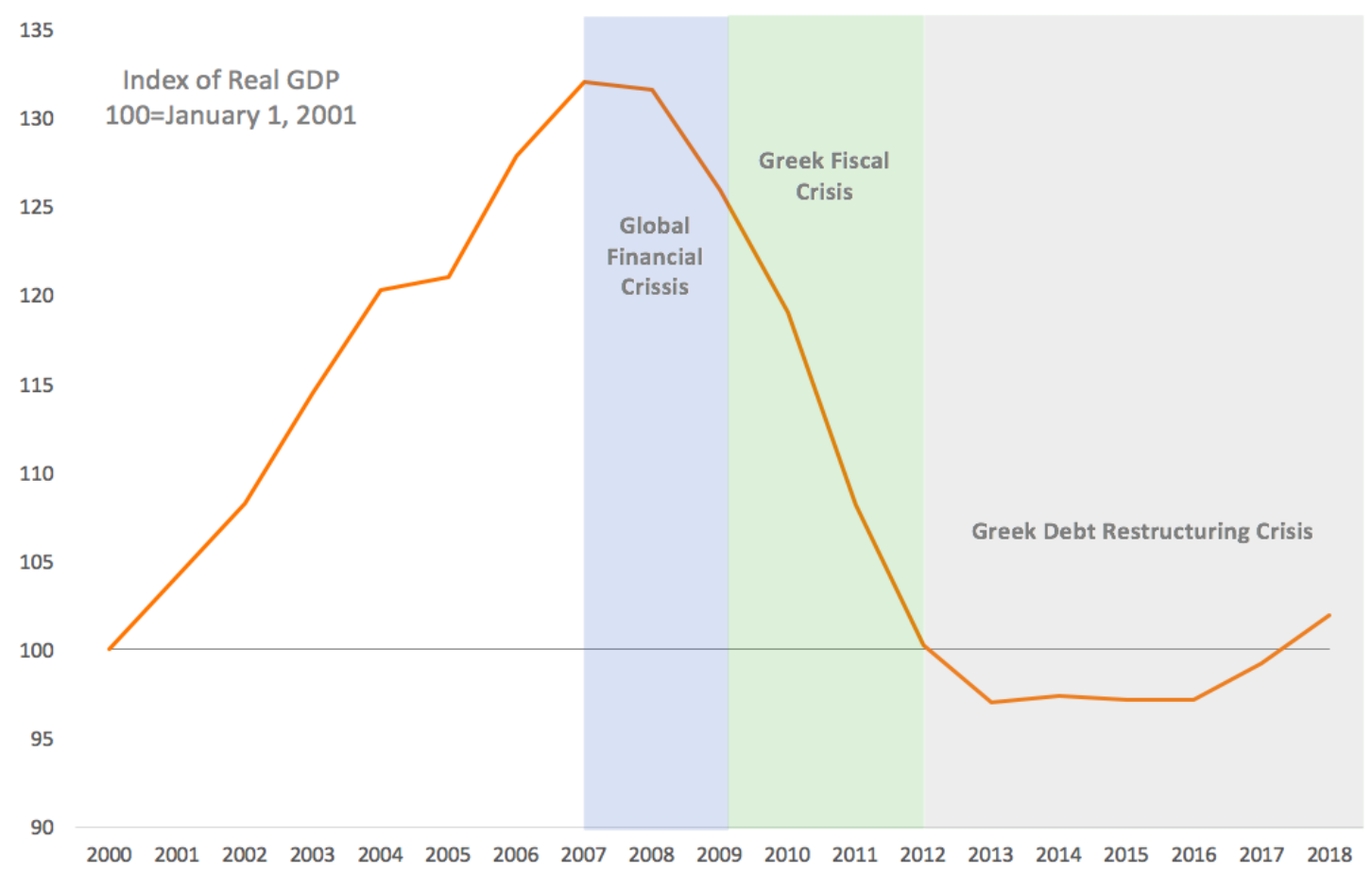

Graph 3. Intensity of loan amount

Source: Cohen and Karatzimas, 2018

\section{Interventions: Past and Present}

\subsection{Intervention in Greece}

According to Cohen and Karatzimas (2018), the Troika had a total of six interventions, in the required countries of which Greece encountered the maximum of three interventions that were based on various factors including loan amount, the intensity of the reforms, policies required, and so on. The intervention began in May 2010 and was considered the first intervention of Troika. The Greek government had a loan of 45 billion Euros in 2010 which computed to 110 billion Euros by three years at the rate of 5 percent which led to huge demonstrations and protests across the country. As per Bleck (2018), owing to the opposition across Greece and the deteriorating situation, the second intervention was initiated for 130 billion Euros, which were not welcomed as well by the citizens. However, as commented by Lykourioti (2018), The European Union created pressure on the Greek government to allow the third intervention of the Troika or leave the European Union involving an amount of 200 billion Euros. On the other hand, to tackle the economic crisis at present different methods are used and according to Johansson et al.(2017), if the situation has arisen now, the country would have taken measures to repay the debts by collecting revenues within the country and also could have asked for help from the World Bank. According to Kalogiannidis et al (2020) the world bank has terms and conditions that are favorable for countries and implement plans for making the proper use of the revenue generated with the help of digitization and technical advances. Greece should focus on the tourism industry as it is one of the key factors that will help you enhance the economy.

\subsection{Intervention in Ireland}

Troika, following the first intervention of Greece, had intervened in Ireland in 2010, in the month of November, and the country was lent an amount of 70 billion Euros, the citizens there were upset with the terms of the troika. As per Griffin et al (2018), for such scenarios, the country should have taken control over the banks and nationalized the use of electronic currency and digital payment along with using seeking ways to promote their products in the world market that would provide them good revenues. The income from the revenues should be used to make infrastructure more reliable that will help in future crises, if any, occurs. Ireland should try to bring their products to the international market, with the help of social media and digital platforms that would provide the country demands. 


\subsection{Intervention in Portugal}

According to Featherstone and Papadimitriou (2017), the troika intervened in Portugal in May 2011 with an amount of 71.4 billion Euros. Dealing with the economic crisis of Portugal has been a challenge for the troika even, as for the stubborn government. According to Roy and Hackett (2017), the country can provide short term reliefs of the basic needs, and ask the banks to deliver the necessities. Portugal can even ask for the neighbouring countries for help, in the form of alliances. If other countries sign to be an alliance and provide work to the country, unemployment can be solved and that would benefit the economic conditions of Portugal.

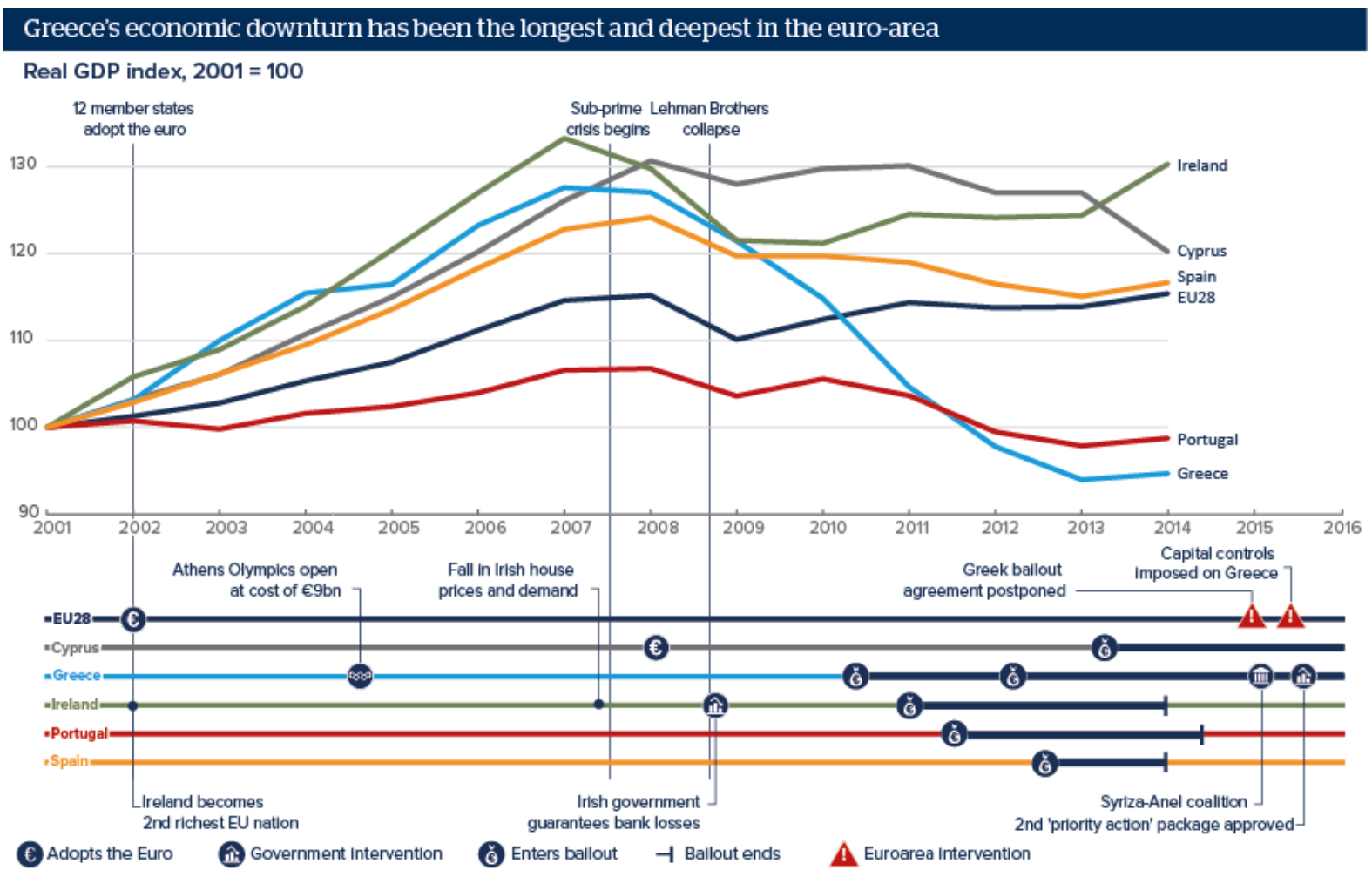

Graph 4. The longest economic downturn in Greece

Source: Featherstone and Papadimitriou, 2017

\section{Pre-intervention}

Ireland and Greece had the fastest growing economy during the period of 1999 to 2008. Greece entered the European Union in 2001 after it was able to convince the authorities that a good economy had met all the required targets. According to Soukiazis et al. (2018), joining the European Union provided Greece with the international market and its growth increased to 4 percent annually until the depression in 2008. After that, the burrowing increased in the country especially in the private sector, though it was less in comparison to Ireland. Therefore, the Greek were less susceptible to the crisis compared to Ireland, adding to it the banking system of Greece was modest in comparison to the other countries of the euro zone, so when the crisis broke Greece compared it to the USA crisis as no such was ever experienced in the Euro zone. 


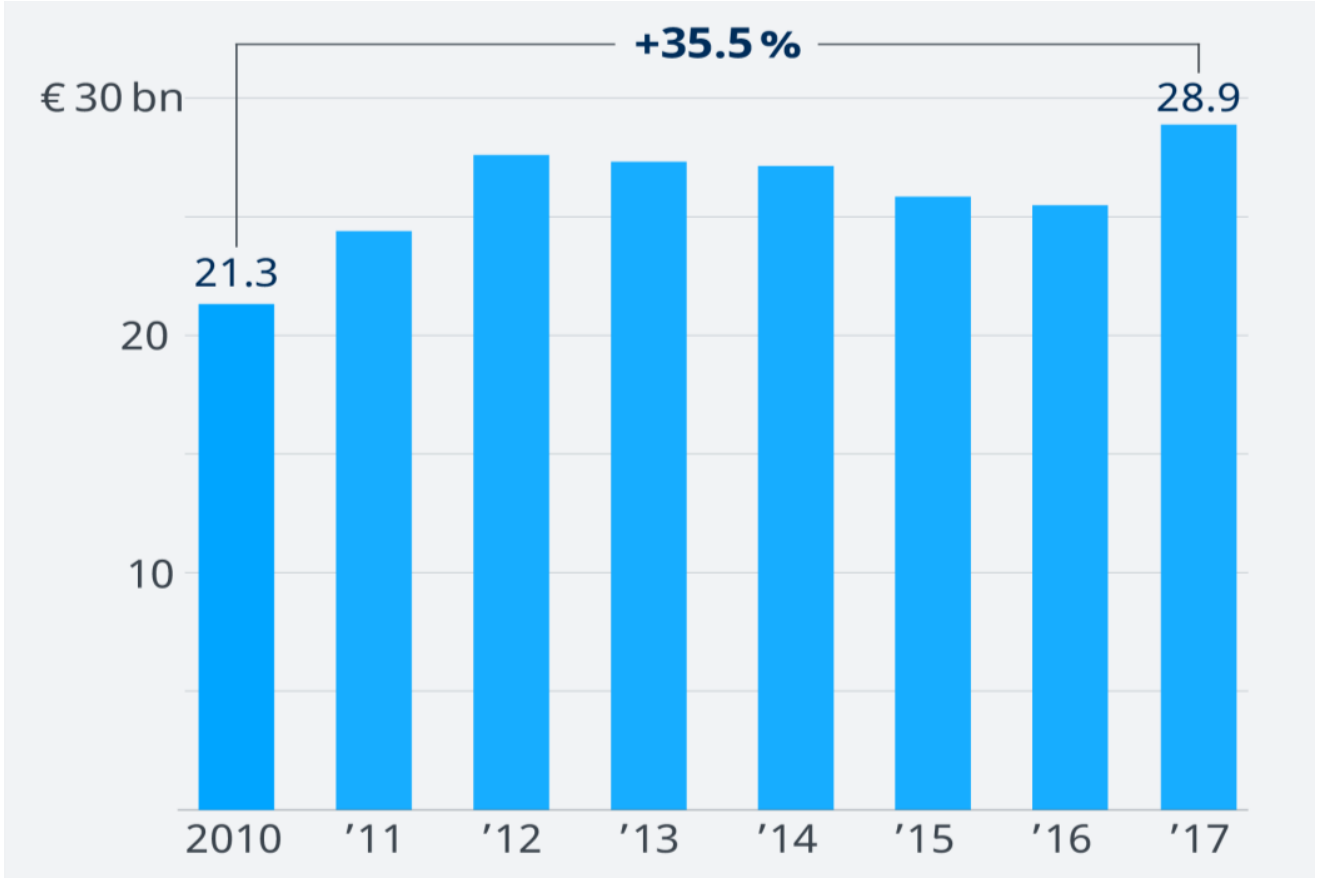

Graph 5. The rising exports in Greece

Source: Haliassos et al. 2017

According to Haliassos et al. (2017), the crisis that had originated, as financial, took the form of a political crisis since 2010, and the new government has announced after five years about the deficit in 2009 that was nearly 12.5 percent of the GDP instead of 3.7 percent, which the previous government declared. The troika has sensed the reason behind the Greece crisis was the irresponsible practices in the economy and corruption by the political members. The trial helped Greece to recognize the need for better reporting of the finances and governing them.

\section{Implementation Outputs}

Moreover, considering the market access and the regain, the Irish methods can be noticed as successful as the country was able to complete the program and exit the troika by the estimated duration along with all the positive outcomes (Haliassos et al. 2017). In the case of Portugal, the program was a bit of a fall, as the expected gap was 2.5 percent but it fell below the limit of 3 percent. Following Ireland, Portugal left the program without seeking any further program or agreement. The third nation to bail out from the program has a four-year-long crisis.

On the other hand, according to Trebesch and Zettelmeyer (2018), the success of the Greek program cannot be judged at the moment. The first intervention or program was renewed with the second agreement after some contradictions on the debts, but still, there is concern whether the country will be able to overcome and regain the market without any further debts. The country, after facing a month-long protest, the agreement was made to repay the debt to the creditors.

On the other hand, Moury and Standring (2017), in order to consider the success, the countries, Greece, Ireland, Portugal, and Cyprus, adopted the revenue merger methods as suggested by the troika. The countries were left with no other choice as their creditors were not interested in offering any more loans. All the programs considered for the respective countries were implemented in order to replenish their economic and financial sectors, and the process is still not completed for all the four countries.

As per Georgi, and Metaxas (2018), considering the situations of Greece and Ireland, further difficulties arose because of cheap access to loans, they need to make some changes in the structure towards the modern economy especially the requirements in the finances. However, the current amount deficient enhanced better than the prediction. Contradicting the situations the outcome was, the trade balance was maintained and the current account has boosted faster than expectations.

According to Selmic (2016), the unemployment rate is still high in the countries and the debts are also outstanding. The economic growth is still not in ample condition that it can regulate the unemployment challenge. Comparing the 
countries, Greece has the highest rate of unemployment, constituting more than 25 percent and a high amount is public debt constituting 175 percent of the country's GDP.

\section{Reformation in Tax Systems to Facilitate Revenue Mobilization}

According to Sidelnykova and Maliuzhets (2019), in order to facilitate revenue mobilization, a number of reforms are required to be made in the tax system and the tax administration in order to make it less rigid and complex. Previously most of the reforms concentrated on the reforms of the structure of the tax system that involved making alterations in the tax base and tax rates. At that time, most nations tried to maintain high insignificant income tax rates as well as immense and fluctuating coverage and rate framework of indirect taxes. But things have changed a lot these days, as tax reformations need to abide by the tax administration keeping in mind the interests of the taxpayers. The reformation in tax systems is not about collecting more revenue but it is about enhancing the basic rudiments of the tax systems which in turn can sustainably increase the revenue and mobilize it in the entire economy of a nation. This helps to strengthen the tax administrative structure as well as building a dynamic economy which helps in the growth and development of the nation. Now reformation in the tax system is about reconciling and reaching a settlement among the challenging objectives like equity, adaptability, balance in macroeconomics, and viability in the environment. An efficient tax system helps to build a mutually beneficial relationship between the government and the citizens which ensures deliverance of the important public services. Van den Boogaard et al. (2018), stated that a flexible and adaptable tax system guarantees citizens of improved governance and in turn, the government is assured of a more predictable source of income. But the government needs to ensure that the tax system is fair and equitable so that it can balance the goal of enhanced revenue mobilization by diminishing the costs of compliance and hence in turn promoting positive growth of the economy of the nation. The World Bank which is the largest provider of development finance has been assisting around 77 countries in resource mobilization having around 173 active engagements.

Akitoby et al. (2018), commented that as a result, the revenue generation of the nation increases considerably which helps the nation to do work more on its development and growth. The effective mobilization of the revenue earned due to improved and reformed tax systems helps to enhance the economy of the country and gives it a momentum to work more for the citizens of the country.

\section{International Support in Revenue Mobilization}

According to Ato Brown et al. (2019), resource mobilization is usually established at a level where it can be effectively analyzed utilizing the tax to gross domestic product (GDP) ratio as one of the key determinants In the low-income countries, the annual growth rate of the tax rate to GDP ratio is quite low at about $1.6 \%$ on an average as recorded between the years 1990 to 2014. The tax rate to GDP ratio for low-income and lower-middle-income nations has been recorded at about $15 \%$ on average which is much low as compared to the standard ratio laid down by the Organization for Economic Co-operation and Development (OECD) for the countries at about 34\%. Monetary (2018), stated that the external support has been seen as one of the effective ways to enhance the tax systems which has shown its impact as a cost-effective approach in mobilizing the revenue within a nation. Earlier mobilizing the revenue of the developing nations was not a priority for the developed nations but things have changed a lot now. Now the approach of the developed nations in reshaping the economy of the developing nations by providing financial assistance in the form of packages or aids in order to have better revenue mobilization is gaining prominence among the different developed nations and has been considered as one the main agenda in building better international relations with the different nations. The collaborative effort from the International Monetary Fund (IMF), the World Bank, and the European Union along with other international organizations have helped a number of nations to identify the flaws in their tax systems and helped them to implement the appropriate corrective measures in order to reform them. Diakite et al. (2019), argued that the collective initiative of the international bodies also helped the international bodies to effectively address the issues of profit sharing and base erosion. This international support to the developing nations in resource mobilization has helped to foster an unexpected level of co-operation on the grounds of technical assistance to tax systems and promoted inclusive policy decisions for the betterment and growth of the nation. Besides giving support, the World Bank has been providing guidance and support to the countries in order to raise revenue and mobilize it by assisting them to bring changes in their tax policies and administration. The World Bank has aided the countries to frame reliable tax systems in order to combat tax evasion by initiating early detection, intelligent auditing, and competitive analysis and pursuit that identify the tax evaders. This has helped the countries to accumulate outstanding taxes and mobilize the revenue in the economy of the nation. The taxpayers also becoming more responsible towards the nation are paying the taxes on time and the flexible and transparent tax system has helped them to gain more confidence in the tax system. 


\section{Impact of Revenue Mobilization on Structural Transformation}

According to Moldovan (2016), revenue mobilization has time and again proved to be a path towards the sustainable development of the economy of a nation and that is why it is considered by most nations as an effective approach towards the development and progress of a nation. In order to ensure optimal mobilization of resources many nations facing the challenges of an unstable economy have brought changes in their tax structure by lifting the tax base and effectively managing the tax revenue. But such steps have mixed outcomes especially when the well-being and interests of the citizens are on the stakes. In order to have greater liability and clarity towards resource management, the government should reinforce its fiscal policy and unbiased public spending. According to Kalogiannidis et al (2020) the government also needs to play an active role in ensuring deeper corporate governance which would promote a wider industrial policy that is required for undergoing a radical transformation. In addition to that international action helps to create a global environment for stronger governance in order to disclose tax evasion, unauthorized financial transactions, and unethical pricing strategies.

The revenue earned from the formal and informal sectors in a nation is difficult to gauge but it forms one of the key indicators to evaluate the economy of a nation. Time and again these sectors have played a pivotal role in the resource mobilization of a nation and also contributed towards the growth and development of a nation by promoting its economy positively. Cevik et al. (2019), stated that a turbulent and volatile international market has always been a barrier towards the effective mobilization of resources and this has been a setback for the economy for that nation. In such cases, the growth and development activity of the nation generally ceases or takes place at a much slower rate than the expected rate. The impact of the output and cost volatility of the resources can go beyond the measurable scope of the economy of a nation. And in such scenarios, if the government takes any inappropriate and incorrect decisions, then the mobilization of resources becomes almost impossible which greatly affects the growth and development of the nation. According to Mavratzas et al (2020) the fiscal harmonization generally helps to tackle the challenge that comes with the illegitimate financial flow into the economy which causes a misbalance in the mobilization of the resources. But timely intervention by the government in order to tackle the problem illicit flow can maintain regularity in the mobilization of the resources. Sawadogo (2019), commented that leveraging the revenue and effective utilization of innovative financial instruments has proved to be crucial in resource mobilization for any nation. The connection between resource mobilization and service delivery has proved to be fruitful for the economy of the nation and also helping in its development and growth. According to Kalogiannidis (2020) a more proactive approach towards resource governance and adopting stringent policies in order to maximize the generation and utilization of resources helps in accomplishing comprehensiveness, sustainable growth, detailed advancement conclusion, and economic transformation. Papaevangelou (2020) stated that has helped in the structural transformation of the economic framework of a nation which has promoted its growth and development on a positive note .

\section{Opportunities and Challenges in Resource Mobilization}

According to Wigger and Alsos (2018), resource mobilization has become a fundamental priority in the agenda towards sustainable growth. The mobilization and optimized utilization of resources has been emphasized time and again in the quest for sustainable development. Taxes and some of the unconventional tax instruments like royalties and rents from resources leased out to extensive establishments and in some cases fees received from public services form the decisive and continuous sources of revenue, on the other hand, the expenditure in the form of legal obligations, administrative overheads, liabilities or debts, and increased payables creates a misbalanced between the two for the government. Now, these have a huge impact on the quality and level of the present-day services as well as it greatly affects the future development and growth of the economy of the nation. Things get aggravated for the government when the revenue reduces considerably but the demand for public services increases manifold, as a result, the government has to depend on borrowings, and excessive borrowing beyond a particular limit can adversely affect the economic growth and resource immobilization. Foreign borrowings come with huge interest rates which lead to high indebtedness. So it provides some initial solution to the problem but it creates a huge liability for the government which in turn slows down the rate of growth and development of the nation. Gregg et al. (2020), argued that these foreign borrowings if effectively allocated into projects and programs that are economically viable and can be developed sustainably surely can bring positive and productive outcomes which can to some extent help in the growth and development of the nation. According to Mukhi and Quental (2019), sustainable development aims to resolve two critical issues: firstly to eradicate global poverty and secondly to protect the environment. The nations across the world constantly strive to perform in order to resolve these two major issues by setting ambitious objectives encompassing the notions of sustainable development along with economic and social growth. But while pursuing these objectives many times, the nations face constraints due to inadequate resource mobilization, as a result on several occasions; the objectives cannot be accomplished and remains unfulfilled. Tax structure reforms and preventing illicit financial 
transactions and corruption happens to be a key to achieving these goals. Effective resource mobilization has been the source of funding for many development programs both at the national and international levels, and it continues to be one of the key funding sources for any nation across the world. So the management of resources can guarantee the optimal mobilization of resources which in turn can help a nation in sustainable development by creating necessary financial support to the programs and plans that ensure the growth and development of the nation. Not only has that it ensured in providing the citizens with necessary services at their disposal without compromising the quality.

\section{Methodology}

After the whole research study the methodologies used is the secondary methods where no analysis or physical surveys are done. The primary methods are not used all the methods are based on the researches and the studies available. The effects that have been observed by the development functions and the statistics that is available after the influence of the growth after the revenue mobilization.

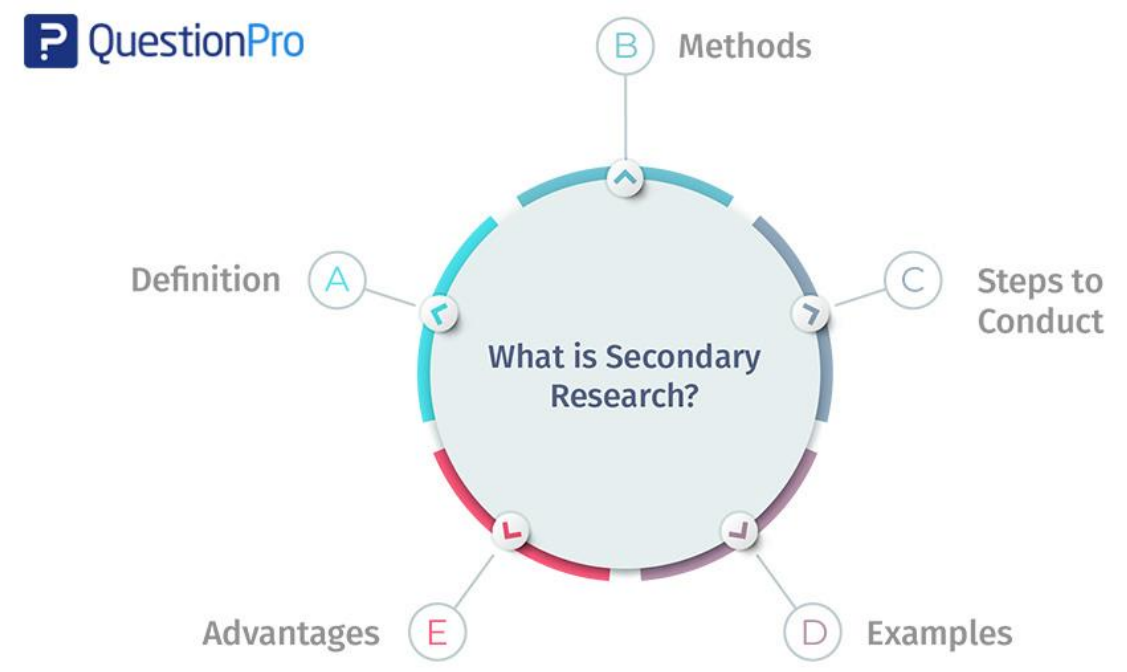

- Definition: the secondary research would focus on the analysis of others principles and using the data set for any other research.

- Methods: includes the internal secondary research data and the external secondary research data.

- Steps to conduct: it could be conducted by the data collection and the analysis done by the others for any other research work.

- Examples: the examples of the secondary research studies are based on the magazines, newspapers, research works, and statistical studies.

- Advantages: the advantages of this research study are that it is cost effective as most of the data and research study are already done.

\section{Concluding Remarks}

Revenue mobilization has been considered as an excellent choice for the development of the economy of a country. Taking help from the International Monetary Fund or the World Bank is considered as debt which has to be repaid, whereas revenue is collected from the country itself as taxation and tariffs. The revenue has helped the government to accumulate capital for various expenditures in the development of the nation such as building infrastructure and improving health facilities. Revenues have been considered significant especially in developing countries. As stated by Coplin and Nwafor (2019), the revenue collection system depends on numerous factors like the financial condition of the State, the product, import tariffs, and so on. Maintaining the revenues and the benefits from it are supported by a strategic implementation that defines the tax policies and the reforms in the country. The rates of taxation applied are both, direct and indirect, where the direct tax is broad and the indirect taxation is frequent. The collection through 
revenue is a show process in building the capital but us more sustainable in the long run.

As in this research, considering the crisis in Greece after the depression of 2008, one of the alternatives to overcome the crisis was the mobilization if the revenue collected. According to Moldovan (2016), revenue mobilization would have saved Greece from the debts, which took a long time to be repaid. In order to encourage revenue mobilization, Greece has to undertake many reforms in the legal system in order to simplify and make the process worthy. As stated by Combes and Ouedraogo (2016), an efficient revenue system helps to build benefits for both the nation and its citizens. Considering the growth of technology, innovations, and technical advantages will help in revenue collection and mobilization for the development of the economy along with better administration.

As stated by Melina and Poplawski-Ribeiro (2020), domestic resources are the major aspect of the development process of the country and economic growth. The revenue modernization has proved itself to be the most stable and sustainable approach. The relation between mobilization and services have resulted in a beneficial fit for the economy and development of the nation. The revenue mobilization has become fundamental in the growth process, emphasizing sustainable development. On the other hand, tax reforms help in the prevention of wrongful expenditures at individual levels, thus lowering the unworthy expenses and helping citizens save for them and the country. As stated Papaevangelou et al (2020) an efficient revenue mobilization will help the country to undertake all the necessary development programs and will be an efficient mode of funding to nations across the globe.

Presently, most of the domestic revenue collected has been by commodities, for this reason, countries deficient of resources have slow revenue mobilization. In order to improve the revenues, the government can use technology, like electronic currency, that would help in tracking the expenses and in collecting the taxes on those expenses Fjeldstad (2016). The better the revenues will be the better it would be to mobilize it and make the most out of it in the growth and development of the economy and the nation altogether.

\section{References}

Akitoby, B., Baum, A., Hackney, C., Harrison, O., Primus, K., \& Salins, V. (2018). Tax Revenue Mobilization Episodes in Emerging Markets and Low-Income Countries: Lessons from a New Dataset. IMF Working Papers, 18(234), 1.

Alexopoulos, I., Kounetas, K., \& Tzelepis, D. (2018). Environmental and financial performance. Is there a win-win or a win-loss situation? Evidence from Greek manufacturing. Journal of Cleaner Production, 197, 1275-1283.

Artavanis, N., Morse, A., \& Tsoutsoura, M. (2016). Measuring income tax evasion using bank credit: Evidence from Greece. The Quarterly Journal of Economics, 131(2), 739-798.

Ato Brown, E., Ofosuhene, S., \& Akenten, W. (2019). Constraints of Revenue Mobilization: Local Government Perspective. SSRN Electronic Journal.

Bitzenis, A., \& Vlachos, V. (2018). Tax morale in times of economic depression: The case of Greece. In Advances in Taxation. Emerald Publishing Limited.

Bleck, M. (2018). How has the quality of democracy in Greece changed due to Troika's intervention?.

Castillo-Manzano, J. I., Castro-Nuño, M., Lopez-Valpuesta, L., \& Boby, J. (2020). Looking for traces of the Troika's intervention in European road safety. Accident Analysis \& Prevention, 137, 105461.

Cevik, S., Gottschalk, J., Hutton, E., Jaramillo, L., Karnane, P., \& Sow, M. (2019). Structural transformation and tax efficiency. International Finance, 22(3), 341-379.

Cohen, S., \& Karatzimas, S. (2018). The role of the Troika on the Greek central government accounting reforms. International Journal of Public Sector Management.

Combes, J. L., \& Ouedraogo, R. (2016). How does inclusive growth boost tax revenue mobilization?

Coplin, N., \& Nwafor, A. (2019). It's Not All About the Money: Domestic revenue mobilization, reducing inequality and building trust with citizens.

Danchev, S., Gatopoulos, G., \& Vettas, N. (2020). Penetration of Digital Payments in Greece after Capital Controls: Determinants and Impact on VAT Revenues. CESifo Economic Studies.

Diakite, M., Diarra, S., Tapsoba, S. J. A., \& Zongo, T. (2019). Foreign Aid and Domestic Revenue Mobilization in Conflict-affected Countries.

Featherstone, K., \& Papadimitriou, D. (2017). Greece: A Crisis in Two-Level Governance. The European Union in Crisis, 233.

Fjeldstad, O. H. (2016). Revenue mobilization at sub-national levels in Sudan. Sudan Report. 
Georgia, D., \& Metaxas, T. (2018). Mapping economic crisis in south Europe: Greece, Portugal and Cyprus.

Chatzitheodoridis, F., Kalogiannidis, S., Kontsas, S. (2020). An Eclectic Discussion of the Effects of COVID-19 Pandemic on the World Economy During the First Stage of the Spread. International Journal of Financial Research, 11(6), Special Issue, 137-153. https://doi.org/10.5430/ijfr.v11n6p137

Gregg, J. S., Nyborg, S., Hansen, M., Schwanitz, V. J., Wierling, A., Zeiss, J. P., .. Gilcrease, W. (2020). Collective action and social innovation in the energy sector: A mobilization model perspective. Energies, 13(3), 651.

Griffin, S. C., Bui, D. P., Gowrisankaran, G., Lutz, E. A., He, C., Hu, C., \& Burgess, J. L. (2018). Risk management interventions to reduce injuries and maximize economic benefits in US mining. Journal of Occupational and Environmental Medicine, 60(3), 226-233.

Haliassos, M., Hardouvelis, G., Tsoutsoura, M., \& Vayanos, D. (2017). Financial development and the credit cycle in greece. Beyond Austerity: Reforming the Greek Economy, 251.

Johansson, A. C., Luo, D., Rickne, J., \& Zheng, W. (2017). Government intervention in the capital allocation process: Excess employment as an IPO selection rule in China. China Economic Review, 44, 271-281.

Jokanović, B., Lalic, B., Milovančević, M., Simeunović, N., \& Marković, D. (2017). Economic development evaluation based on science and patents. Physica A: Statistical Mechanics and its Applications, 481, 141-145.

Kalogiannidis, S. (2021). The Effects of Total Quality Management Practices and Marketing on Performance of SMEs. A Case of Selected Manufacturing Industries, Greece. Business Management and Strategy, 12(1), 48-62. https://doi.org/10.5296/bms.v12i1.17995

Kalogiannidis, S. (2020). Covid Impact on Small Business. International Journal of Social Science and Economics Invention, 6(12), 387-391. https://doi.org/10.23958/ijssei/vol06-i12/257

Stavros, K. (2020). Impact of Plant Closures on Urban and Regional Communities: A Case Study of South Australian Gas Industry and its Workers. International Journal of Economics and Business Administration, VIII(4), 994-1010. https://doi.org/10.35808/ijeba/645

Kalogiannidis, S. (2020). Impact of Effective Business Communication on Employee Performance. European Journal of Business and Management Research, 5(6). https://doi.org/10.24018/ejbmr.2020.5.6.631

Kalogiannidis, S. (2020). Economic Cooperative Models: Agricultural Cooperatives in Greece and the Need to Modernize their Operation for the Sustainable Development of Local Societies. International Journal of Academic Research in Business and Social Sciences, 10(11), 452-468. https://doi.org/10.6007/JJARBSS/v10-i11/8035

Kamaras, A. (2020). Renewing Diaspora Studies in Greece: a Research Agenda. Policy.

Karagiannaki, A., Vergados, G., \& Fouskas, K. (2017). The impact of digital transformation in the financial services industry: insights from an open innovation initiative in fintech in Greece. In Mediterranean Conference on Information Systems (MCIS). Association For Information Systems.

Karavitis, N. E. (2018). Fiscal adjustment and debt sustainability: Greece 2010-2016 and beyond (No. 245).

Khodaiji, J. D., \& Christopoulou, D. (2020). Sustainable development and the circular economy in Greece: case examples from Costa Navarino and Grecotel. Worldwide Hospitality and Tourism Themes.

Kontolaimou, A., \& Skintzi, G. (2018). 4.2. digitisation patterns of the Greek economy and society. Greek Economic Outlook, 2018(37), 41-48.

Lois, P., Drogalas, G., Karagiorgos, A., \& Chlorou, A. (2019). Tax compliance during fiscal depression periods: the case of Greece. EuroMed Journal of Business.

Lykourioti, L. (2018). The Troika and public administration reform in Greece: the role of the crisis and the power of bureaucracy.

Mavratzas, S., \& Kalogiannidis, S. (2020, December). Impact of marketing mix strategies effective product development issues in MNCs/Retail. International Journal of Business Marketing and Management (IJBMM), 5(12), 118-125.

Meghir, C., Pissarides, C. A., Vayanos, D., \& Vettas, N. (Eds.) (2017). Beyond austerity: reforming the greek economy. Mit Press.

Melfou, K., \& Kalogiannidis, S. (2020). Issues and Opportunities for Agriculture Sector During Global Pandemic. International Journal of Economics, Business and Management Research, 4(12), 204-211. 
Melina, G., \& Poplawski-Ribeiro, M. (2020). Macroeconomic impacts of non-resource revenue mobilization in CEMAC. Applied Economics Letters, 1-6.

Moldovan, O. (2016). Local Revenue Mobilization in Romania. European Financial and Accounting Journal, 11(3), 107-124.

Monetary, I. (2018). Georgia. Washington, D.C.: International Monetary Fund.

Moschella, M. (2016). Negotiating Greece. Layering, insulation, and the design of adjustment programs in the Eurozone. Review of International Political Economy, 23(5), 799-824.

Moury, C., \& Standring, A. (2017). 'Going beyond the Troika': Power and discourse in Portuguese austerity politics. European Journal of Political Research, 56(3), 660-679.

Mukhi, U., \& Quental, C. (2019). Exploring the challenges and opportunities of the United Nations sustainable development goals: a dialogue between a climate scientist and management scholars. Corporate Governance: The International Journal of Busin.

Papaevangelou, O., \& Kalogiannidis, S. (2020). Impact of Business Communication on the Performance of Adult Trainees. International Journal of Academic Research in Progressive Education and Development, 9(3), 213-222. https://doi.org/10.6007/IJARPED/v9-i3/8154

Papaevangelou, O., Kalogiannidis, S., \& Melfou, K. (2020). Global Marketing Strategic Approaches on Multi National Companies Product Development. International Journal of Scientific Research and Management, 8(12), 2084-2090. https://doi.org/10.18535/ijsrm/v8i12.em08

Popoola, O., Asaleye, A. J., \& Eluyela, D. F. (2018). Domestic revenue mobilization and agricultural productivity: evidence from Nigeria. Journal of Advanced Research in Law and Economics, 9(4(34)), 1439-1450.

Roy, M. J., \& Hackett, M. T. (2017). Polanyi's 'substantive approach' to the economy in action? Conceptualising social enterprise as a public health 'intervention'. Review of Social Economy, 75(2), 89-111.

Sawadogo, I. (2019). Fiscal revenues and macroeconomic effects: the case of Burkina Faso.

Selmic, R. (2016). The European Central Bank, machinic enslavement, and the Greek public sector. Finance and Society, 2(1), 45-61.

Sidelnykova, L., \& Maliuzhets, O. (2019). Forecasting of Potential Budget Possibilities for Tax Revenue Mobilization. Economy and Society, (20).

Soukiazis, E., Antunes, M., \&Kostakis, I. (2018). The Greek economy under the twin-deficit pressure: a demand orientated growth approach. International Review of Applied Economics, 32(2), 215-236.

Sukhanov, A. V., Prokof'Ev, I. V., \& Ivanov, A.V. (2016). A universal digital platform for the construction of self-organizing wireless sensor networks for industrial safety and ecological monitoring systems. Russian microelectronics, 45(2), 137-141.

Taplin, J. (2017). Move fast and break things: How Facebook, Google, and Amazon have cornered culture and what it means for all of us. Pan Macmillan.

Theodoropoulou, S. (2016). Severe pain, very little gain: internal devaluation and rising unemployment in Greece. Unemployment, internal devaluation and labour market deregulation in Europe. Brussels: ETUI.

Trebesch, C., \& Zettelmeyer, J. (2018). ECB interventions in distressed sovereign debt markets: The case of Greek bonds. IMF Economic Review, 66(2), 287-332.

van den Boogaard, V., Prichard, W., Benson, M., \& Milicic, N. (2018). Tax Revenue Mobilization in Conflict-affected Developing Countries. Journal of International Development, 30(2), 345-364.

Wigger, K., \& Alsos, G. (2018). Resource Mobilization for Temporary Opportunities. Academy of Management Proceedings, 2018(1), 15961.

\section{Copyrights}

Copyright for this article is retained by the author(s), with first publication rights granted to the journal.

This is an open-access article distributed under the terms and conditions of the Creative Commons Attribution license (http://creativecommons.org/licenses/by/4.0/). 